\title{
Zonation Systems on New Student Admission Policies For Equality of Education in Indonesia
}

\author{
Sonia Rahma Feberliantika ${ }^{1}$, Hasan Hariri ${ }^{2 *}$, Showiyah ${ }^{3}$, Riswanti Rini ${ }^{4}$ \\ ${ }^{1}$ Department of Educational Administration, University of Lampung, Indonesia. \\ ${ }^{2,3,4}$ Department of Educational Administration, University of Lampung, Indonesia. \\ * Corresponding Author. E-mail: ${ }^{1}$ soniarhmp@gmail.com
}

\begin{abstract}
Abstrak
Penelitian ini bertujuan untuk menunjukkan permasalahan yang terjadi mengenai penerapan sistem penerimaan peserta didik baru melalui sistem zonasi, dampak dan implikasi dari berbagai kendala dan permasalahan dari penerapan sistem zonasi dalam penerimaan peserta didik baru. Penelitian ini merupakan penelitian kepustakaan dengan sumber data menggunakan studi sebelumnya dan informasi dari media massa terpercaya. Hasil penelitian menjelaskan bahwa ada beberapa permasalahan yang perlu diselesaikan agar penerapan sistem zonasi dalam kebijakan penerimaan mahasiswa baru dapat dilakukan secara optimal. Permasalahannya adalah mengurangi kapasitas jalur prestasi, kondisi akreditasi sekolah yang belum merata, dan banyak sekolah yang belum memadai kondisi ruang kelasnya. Dampak yang ditimbulkan dari penerapan sistem zonasi adalah memudahkan peserta didik untuk bersekolah, memeratakan kualitas sekolah, dan menimbulkan persepsi keterbatasan pilihan sekolah bagi peserta didik.
\end{abstract}

Kata Kunci: Sistem Zonasi, Pemerataan Pendidikan, dan Penerimaan Peserta Didik Baru

\begin{abstract}
This research aims to show the problems that occur regarding the application of the new student admission system through the zoning system, the real impact and the implications of various constraints and problems from the application of the zoning system in acceptance of new students. This research is a literature research with data resources using previously study and information from trusted mass media. The results of the study explain that there are several problems that need to be resolved so that the application of the zoning system in the new student admissions policy can be carried out optimally. The problem is reducing the capacity of the achievement pathway, the condition of school accreditation is not evenly distributed, and many schools have inadequate classroom conditions. The impact of the implementation of the zoning system is that it makes it easier for students to attend school, equalizes the quality of schools, and creates perceptions of the limitations of school choices for students.
\end{abstract}

Keywords: Zoning system, Equality of Education, and New Student Admission. 


\section{Introduction}

Education is one of the fundamental aspects for the development of mankind around the world. Higher education can be the basis for someone to be able to provide benefits for the development of life. As expressed by Ismabela (2020), education is the basis for humans to explore new knowledge and improve the quality of human resources. The better the quality of human resources, the greater the chance of the individual concerned to develop rapidly and become individually successful. For a country, the greater the number of qualified human.

Education is one of the efforts to increase the academic and non-academic potential of individuals in carrying out the functions and goals of national education, one of which is to educate the nation's life. Education itself can be defined as an experience or life [1]. In Indonesia, education is the right of all people which is also explained in the 1945 Constitution, where the government has the obligation to fulfill the right to obtain proper education to determine the quality of life of the community.

The implementation of education in Indonesia until entering the beginning of 2021 still has problems, namely equal distribution of the quality of education for all parts of Indonesia. This is expressed in Anjarwati \& Rochmat (2020) which explains that equal access and quality of education is still a special concern for the central government. Furthermore, Anjarwati \& Rochmat (2020) revealed that there are two aspects that need to be considered during the educational equality process, namely access to education that can be felt by all Indonesian people who are entering school age and access to education without paying attention to differences in ethnicity, religion, and certain groups.

One form of educational inequality that occurs in Indonesia is in terms of facilities and infrastructure, where in big cities educational facilities and infrastructure are already advanced and tend to be more complete than the educational facilities and infrastructure available in villages or remote areas of
Indonesia [2]. In addition to the problems of facilities and infrastructure, affordability of school fees is also an obstacle, where people with weak economic conditions experience difficulties in obtaining proper education.

Based on these problems, it is important for the government to make efforts to increase equitable access to education. One of the steps that was then taken by the government was to regulate the student admission system policy using the zoning system. The policy for the admission of participants through the zoning system has been in effect since the 2017/218 academic year as outlined in the Regulation of the Minister of Education and Culture Number 17 of 2017. The policy was then updated twice, in 2018 through the Regulation of the Minister of Education and Culture Number 14 of 2018 and Regulation Minister of Education and Culture Number 51 of 2018. The purpose of the renewal of the Regulation of the Minister of Education and Culture regarding the zoning system for student admission is to encourage increased access to education services and equitable quality of education [3].

Technically disclosed by [4] that the implementation of the zoning system can lead to creating greater opportunities for children who live close to the school to be able to enter the school even though they do not meet the requirements of the national exam (UN/USBN). This condition is expected to gather students with various academic and non-academic abilities in one class, which will also affect the learning process. Indirectly, the efforts made by the government through the zoning system are to erase the perception of superior schools and non-superior schools in the community.

In terms of the zoning system is a criterion in the New Student Admissions System (PPDB) which takes into account the distance between the residence of prospective students and the educational unit as the main aspect and not based on the national exam scores (UN/USBN). The zoning system also forces schools to accept $90 \%$ of students who are registrants with the criteria for a zone close to the school, $5 \%$ for high achieving students, and $5 \%$ students with special academic and non-academic abilities. 
The condition of this zoning system policy then creates strengths and weaknesses based on the acceptance of new students for the 2018 academic year [5]. The advantages of the zoning system in the admission of new students are: (1) there is an equal distribution of students who excel in each school; (2) enabling private schools and public schools to meet the quota of student applicants; (3) can reduce the number of students who drop out of school, because of the ease of being able to register for school at the nearest school; (4) the cost burden borne by parents is getting smaller because the school is located close to where they live; and (5) parents can easily supervise their children during the teaching and learning process at schools close to their homes. The weaknesses of the zoning system itself are: (1) students' learning motivation is lacking because the chances of being accepted at the nearest school are greater and students no longer have a target to attend top schools; (2) students have limitations in registering to the school they want, as an example, students with low academic abilities will have difficulty following the learning, when schools that are near their homes are excellent schools. The weaknesses that have been described are also expressed as problems in applying the zoning system to the admission of new students in the research of Sriandewi, Wirantari, \& Yudharta (2020), that the application of the zoning system limits the rights of students to be able to determine the desired school.

The application of the zoning system to the admission of new students is indeed a new matter for the education system in Indonesia, however the zoning system has also been implemented in developed countries, such as Japan. Research conducted by Akabayashi (2006) revealed that the implementation of the zoning system can actually have an impact on improving the quality of education in schools in urban areas due to an increase in school choices. On the other hand, the application of the zoning system has a small contribution to student achievement.

Based on the description that has been explained, this research was conducted to be able to show the problems that occur in the field regarding the application of the new student admission system through the zoning system, the real impact of the application of the zoning system on student achievement, and the implications of various constraints and problems from the application of the zoning system in acceptance of new students.

\section{Methods}

This research is a literature research. According to Zed (2004), literature research represents activities related to library data, reading, and taking notes and processing research materials. Sugiyono (2013) adds that library research is research that studies theoretically every phenomenon related to culture, values and developing norms. Data collection carried out in this study was obtained from news and articles on trusted online news portals, in addition to using publication journals that are relevant to the research objectives.

The research data source is a secondary data source, because the data is obtained from news, articles and journal publications. The research data collection technique is carried out by means of documentation, namely analyzing the variables or subject being studied through notes, books, papers, news articles, and journal publications [10].

The data that has been collected is then analyzed descriptively qualitatively with three stages [11], namely:

1. Data reduction

Researchers review the data to retrieve relevant data and rule out data that are inconsistent with this study.

2. Data presentation

After the data obtained is reduced, then the data is presented in the form of descriptions, charts, the relationship between categories, flowcharts and the like, making it easier for analysis and interpretation.

\section{Making Conclusion}

The conclusion in qualitative research is the findings obtained from the analysis of data to answer research problems. The analysis is carried out inductively by promoting the thoughts and understanding of researchers who refer to the relevant theory. 


\section{Results And Discussion}

\section{Implementation Of A Zonation System For Admission Of New Students}

Acceptance of students in an educational institution is important. This is because the admission of students who are managed professionally will benefit the school in the field of registration who will later become students in the educational institution. It was further explained that the admission of new students is management, where if no students are accepted, the school or educational institution does not have to be handled [12]. Therefore, the acceptance of new students is something that needs to be determined quickly and accurately [1]. In Indonesia, the new student admissions policy is implementing a zoning system.

The policy regarding the zoning system is one of the educational policies on the acceptance of new students contained in the Regulation of the Minister of Education and Culture Number 14 of 2018. The initial purpose of the zoning system policy is to eliminate educational discrimination that occurs so that the quality of education can be generalized in each region. The regulation explains that schools are required to accept at least $90 \%$ of students who live in zones according to local government regulations. The zoning system policy also allows students to prefer to study in a neighborhood near their home. This is also expressed in Van Meter \& Van Horn (1975) regarding the implementation of policies intended as the overall actions taken by individuals or groups of government or private which are directed at achieving predetermined policy objectives.

The zoning policy carried out by the government is basically different from the expectations of the community in general. This is because parents generally want quality schools for their children. In addition, the main factor that determines school selection is the school's favorite level [3]. This shows that there is a difference between community expectations and government goals through the zoning system policy in terms of school selection.

According to Dewi \& Septiana (2018), the benefits of the zoning system policy are: (1) encouraging educators' creativity in learning with diverse student conditions; (2) assisting the government in providing confirmation in providing assistance to make it more targeted, both in the form of school infrastructure, as well as improving the quality of education provided to the quality of teaching staff; (3) encourage the participation of local governments and the community in efforts to equalize the quality of education as mandated in the law.

Prior to the enactment of the zoning system, there was a zoning system regulated in Government Regulation No. 17 of 2010 concerning the management and implementation of education. This regulation was later changed to Government Regulation Number 66 of 2010. Article 53 paragraph (1) of the regulation explains that secondary education units and higher education units organized by the government or local governments in accordance with their respective authorities are required to allocate places for prospective citizenship students. Indonesia, which has sufficient academic potential and is economically disadvantaged, is at least $20 \%$ of the total number of new students. Referring to the regulation, it can be explained that basically the Regulation of the Minister of Education and Culture Number 14 of 2018 is the implementation of Article $53 \mathrm{~A}$ paragraph 1 of Regulation Number 66 of 2010.

In connection with the implementation of the zoning system on the admission of new students, the results of research from Sinaga, Siahaan, Pardede, \& Siahaan (2020) who conducted research on the implementation of the zoning system in Medan City, showed that there are still several things that need attention. What is meant is the reduction in the number of students accepted from the achievement path in each school. Such conditions can cause a sense of injustice among students who have achievements who want to register.

According to research from Anjarwati \& Rochmat (2020) who conducted research on parents' perceptions of the zoning system in the acceptance of new students in Blitar City, explaining the results that the implementation of the zoning system was effective in updating administrative patterns, however, there were 
Jurnal Edumaspul, 5 (2), Year 2021- 460

(Sonia Rahma Feberliantika, Hasan Hariri)

substantial problems that had to be addressed immediately. The problem in question is regarding school accreditation. The Ministry of Higher Education has a policy of providing a $30 \%$ quota for the National Selection of State Universities (SNMPTN) or the achievement path based on school accreditation. A high school with $A$ accreditation will get a quota of $40 \%$ from the best students, a B accredited high school will get a $25 \%$ quota for the best students, and a high school with a C accreditation will get a $5 \%$ quota for the best students. Taking into account this policy from the Ministry of Higher Education, there is a big challenge for the school zoning policy, namely increasing school accreditation, so that students who have graduated can get a large quota opportunity in the achievement path of new student admissions in higher education.

In the research conducted by Pangaribuan \& Hariyati (2019) which examined the implementation of the zoning system policy in Gresik Regency, it was explained that the implementation of the zoning system policy was based on equal distribution of education quality. Equitable quality of education in question is the availability of facilities and infrastructure that is evenly distributed in every school and the performance of competent teachers. However, if the quality of education cannot be generalized in a fast tempo, it will have a substantial impact on the future education of students, due to limited access to be able to continue higher education.

Regarding the availability of facilities and infrastructure, the following is shown regarding the condition of classrooms for elementary schools to vocational high schools in Indonesia in 2020 .

Table 1 Condition of School Classrooms at Each Level of Education in 2020

\begin{tabular}{|c|c|c|c|c|}
\hline \multirow[b]{2}{*}{$\begin{array}{l}\text { Education } \\
\text { al level } \\
\text { (public } \\
\text { and } \\
\text { private) }\end{array}$} & \multicolumn{3}{|c|}{ Classroom Condition (\%) } & \multirow[b]{2}{*}{$\begin{array}{c}\text { Tota } \\
1\end{array}$} \\
\hline & $\begin{array}{c}\text { Goo } \\
\text { d }\end{array}$ & $\begin{array}{c}\text { Slight / } \\
\text { Moderat } \\
\text { e } \\
\text { Damage }\end{array}$ & $\begin{array}{c}\text { Heavy } \\
\text { Damag } \\
\text { e }\end{array}$ & \\
\hline $\begin{array}{l}\text { Elementar } \\
\text { y School }\end{array}$ & $\begin{array}{c}13,5 \\
9\end{array}$ & 78,79 & 7,63 & 100 \\
\hline $\begin{array}{c}\text { Junior } \\
\text { High }\end{array}$ & $\begin{array}{c}17,1 \\
3\end{array}$ & 77,53 & 5,35 & 100 \\
\hline
\end{tabular}

\begin{tabular}{ccccc}
\hline School & & & & \\
\hline $\begin{array}{c}\text { Senior } \\
\text { High }\end{array}$ & 27,1 & 70,20 & 2,70 & 100 \\
$\begin{array}{c}\text { School } \\
\text { Vocational }\end{array}$ & 29,8 & 68,62 & 1,50 & 100 \\
high & 8 & & & \\
School & & & & \\
\hline
\end{tabular}

Source: Badan Pusat Statistik (2020).

Table 1 shows that the condition of the classrooms at every level of education, from elementary school to senior high school and vocational high school is more than $60 \%$ in a slightly damaged and moderately damaged condition. At the elementary school level, it showed good classroom conditions with the lowest percentage, namely $13.59 \%$, while senior high schools and vocational high schools showed a larger percentage of classroom conditions, namely $27.10 \%$ and $29.88 \%$, respectively. The condition of the main facilities in the implementation of education, which the majority are in unfavorable conditions, is certainly an obstacle in the implementation of zoning policies in student admissions. As explained by Saharuddin \& Khakim (2020) that the lack of educational facilities and infrastructure makes students who feel they have more potential not willing to attend schools with poor classroom conditions and choose to attend favorite schools that tend to have adequate facilities. even though it's far from home.

\section{Impact and Implication Of Implementation Of A New Student Admission Zonation System For Education Equity}

The new student admission system with a zoning system has been carried out since 2018. The implementation of the zoning system by the government basically aims to support equitable access and quality of education. Regarding this date, there are several perspectives from education actors, consisting of teachers and school principals in responding to the implementation of the zoning system for the acceptance of new students. This is explained through the results of research conducted by Pradewi \& Rukiyati (2019).

The first perspective explained is that the application of a zoning system for new 
student admissions can provide easy access for the community to attend school. The zoning system can help students to save travel time to school and transportation costs. This is in line with what has been described by Mandic et al. (2017) that the zoning scheme for the admission of school students is expected to provide comfort for attending schools close to home.

The next perspective is that zoning in student admissions is able to equalize the quality of schools. This is influenced by the variation of input from students who excel in the school. Through zoning acceptance, students in schools become varied both in terms of academic and non-academic. Such conditions can slowly equalize the quality of schools, so that the label of favorite school will slowly disappear in the perception of parents. But on the other hand, this condition can reduce the quality of schools that were originally included in the favorite labeled schools. School achievement will decrease due to variations in the academic level of students. This condition is because the zoning system prioritizes the area of residence rather than student achievement.

This perspective is inversely proportional to the statement of Perdu \& Sheetz (2008) which explains that the quality and quality of schools can be improved through four steps, namely there is good human resource management and service, being able to design the quality of education provided in accordance with the expectations of parents and students, providing quality educational facilities, and being able to establish good communication with parents. When schools can improve these four things, schools need not worry about the impact of the zoning system that can reduce the quality of school education.

Regarding the quality of school education, according to the results of research from Sinaga et al. (2020) explains that the application of the zoning system in the admission of new students can reduce the number of students accepted through the achievement path in each school. This will create a feeling of unfairness among students who have achievements who want to register.
The next perspective is that the application of the zoning system for new student admissions tends to limit the choice of schools for students. Students become less free to determine which school to choose. Bunar (2010) explains that the zoning system will lock students' opportunities to choose schools that are in a different environment from where they live. This is because the purpose of the zoning system is to equalize students in each school.

The next perspective explains that the application of the zoning system will have a more optimal impact when followed by equitable distribution of educational facilities and infrastructure. This is also revealed in the Nepal (2016) which explains that good lighting, a comfortable, safe environment, good building conditions, quality of maintenance of facilities and infrastructure can determine students are willing to attend schools close to their living environment. Therefore, the existence of this zoning system will encourage schools to immediately fix facilities and infrastructure to support students in obtaining a good education [4].

In relation to the distribution of school facilities and infrastructure, research conducted by Hoerudin (2019) explains that the application of the zoning system for the acceptance of new students in the city of Bandung has an impact that tends to be unfavorable for students. This impact is a result of inadequate school facilities and infrastructure, as explained in Hoerudin (2019) that there are schools that have insufficient capacity to accommodate new students who are included in the school zone. This is certainly a bad thing for students, because it becomes difficult to get to school. This is also explained in the research results of Bakar et al. (2019) and Hijrawadi, Adrian, Syahrul, \& Yustika (2020) that the impact of the zoning system is the emergence of schools that have excess students and schools that lack students. The impact also on teachers or educators is experiencing a reduction in teaching time due to lack of students.

There are also impacts arising from the application of the zoning system in the acceptance of new students. The impact in question is that the application of the zoning 
system can increase the desire of students not to continue school. This is due to the limited number of schools that can be selected as schools of choice [24].

\section{Conclusion}

Based on the results of the research and discussion, it can be explained that the implementation of the new student admission zoning system that has been implemented since 2018 tends to still face a number of problems. The first problem is that the zoning system tends to reduce the capacity to accept students through the achievement pathway for each school. The next problem is the uneven condition of school accreditation. The next problem is school infrastructure that is not evenly distributed, there are still many schools in Indonesia that have classrooms that have mild to moderate damage for each level of education up to $70 \%$.

The impact and implications of the implementation of the zoning system for the acceptance of new students in an effort to equalize education is that the zoning system can facilitate access to school, because it prioritizes the distance between the school and the place of residence. The zoning system can also equalize the quality of schools, but the distribution tends to be less good. This is because there are still several evaluations supporting the implementation of the zoning system such as the condition of facilities and infrastructure in each school in each region in good condition. As a result, the perception that arises is that students have limitations in choosing a good school. The further impact is that there is a risk that students prefer not to go to school.

Based on the conclusions of the research results, the suggestion that can be put forward is that the central government can evaluate the application of the zoning system for the application of new students in each region. The evaluation can be carried out regarding school readiness, school capacity, classroom conditions, and comfort. Local governments can also allocate budgets to accelerate the distribution of school facilities and infrastructure in each region, the goal is that each school can have better quality to provide good education to students. Thus, it is expected that students will have the flexibility in choosing schools, because each school has good and equitable facilities and infrastructure in each area.

\section{References}

[1] J. Ismabela, "The Impact of Zoning System to Student Achievement and School Innovation," Adv. Soc. Sci. Educ. Humanit. Res., vol. 387, pp. 292-294, 2020.

[2] S. Anjarwati and Rochmat,

"Pembaharuan Akses Pendidikan: Studi Persepsi Orangtua Peserta Didik Terhadap Sistem Zonasi Dalam Penerimaan Peserta Didik Baru (PPDB) Di Kota Blitar," J. Translitera, vol. 9, no. 2, pp. 35-44, 2020.

[3] G. I. Pradewi and R. Rukiyati, "Kebijakan Sistem Zonasi Dalam Perspektif Pendidikan," J. Manaj. dan Supervisi Pendidik., vol. 4, no. 1, pp. 28-34, 2019.

[4] K. A. A. Bakar, Y. Supriyati, and I. Hanafi, "The Evaluation of Admission Student Policy based on Zoning Sys-tem for Acceleration Education Quality in Indonesia," J. Manag. Info, vol. 6, no. 2, pp. 19-24, 2019.

[5] K. E. Dewi and R. Septiana, "Evaluation of Zoning Student Recruitment System in Year 2018," Proceeding Int. Semin. Educ. Innov. Issues Challenges Educ. Educ. Sustain. Univ. Sarjanawiyata Tamansiswa., pp. 109-115, 2018.

[6] N. L. P. Y. Sriandewi, I. D. A. P. Wirantari, and I. P. D. Yudharta, "Implementasi kebijakan tentang penerimaan peserta didik baru dengan sistem zonasi sekolah pada zona kedua di smp negeri denpasar," IImu Adm. Negara, vol. 1, no. 1, pp. 1-6, 2020.

[7] H. Akabayashi, "Average Effects of School Choice on Educational Attainment : Evidence from Japanese High School Attendance Zones," Proceddings Econ, pp. 1-52, 2006.

[8] M. Zed, Metode Penelitian Kepustakaan. Yayasan Pustaka Obor Indonesia, 2004.

[9] Sugiyono, Metode Penelitian Pendidikan Pendekatan Kuantitatif Kualitatif, dan $R$ 
\& D. Bandung: Alfabeta, 2013.

[10] S. Arikunto, Prosedur Penelitian Suatu Pendekatan Praktik. Jakarta: Rineka Cipta, 2016.

[11] L. J. Moleong, Metode Penelitian Kualitatif, 30th ed. Jakarta: Remaja Rosdakarya, 2017.

[12] A. U. W. Sari, I. Ali, and S. Ahmad Yusuf, "Efektivitas Penerimaan Peserta Didik Baru (PPDB) Melalui Sistem Penerimaan Peserta Didik Online," Pros. Semin. Nas. Mhs. Kerjasama Direktorat Jenderal Guru dan Tenaga Kependidikan Kemendikbud, pp. 1-11, 2016.

[13] D. S. Van Meter and C. E. Van Horn, "The Policy Implementation Process: A Conceptual Framework," Adm. Soc., vol. 6, no. 4, pp. 445-488, 1975.

[14] D. Sinaga, M. Siahaan, S. Pardede, and N. Siahaan, "Efektivitas Penerimaan Peserta Didik Baru Dengan Sistem Zonasi Di Sma Negeri Kota Medan Sesuai Dengan Permendikbud No.12 Tahun 2017," J. Suluh Pendidik., vol. 8, no. 1, pp. 20-25, 2020.

[15] E. N. Pangaribuan and N. Hariyati, "Implementasi Kebijakan Sistem Zonasi Penerimaan Peserta Didik Baru Jenjang SMP di Kabupaten Gresik," Inspirasi

Manaj. Pendidik., vol. 7, no. 1, pp. 1-12, 2019.

[16] Badan Pusat Statistik, "Statistik Pendidikan: Potret Pendidikan Indonesia," Jakarta, 2020.

[17] E. Saharuddin and M. S. Khakim, "Implementasi Kebijakan Sistem Zonasi Dalam Penerimaan Peserta Didik Baru
Pada Tingkat Sma Di Daerah Istimewa Yogyakarta," J. Ilm. IImu Adm. Negara, vol. 7, no. 3, pp. 424-438, 2020.

[18] S. Mandic et al., "Adolescents' perceptions of cycling versus walking to school: Understanding the New Zealand context," J. Transp. Heal., vol. 4, pp. 294-304, 2017.

[19] R. R. Perdu and S. D. Sheetz, Quality System Management and Education in Service Environments, Service Sc. New York: Springer, 2008.

[20] N. Bunar, "The controlled school market and urban schools in sweden," J. Sch. Choice, vol. 4, no. 1, pp. 47-73, 2010.

[21] B. Nepal, "Relationship Among School" S Infrastructure Facilities, Learning Environment and Student 'S Outcome," Int. J. Res. Soc. Sci. Humanit. Res., vol. 2, no. 5, pp. 44-57, 2016.

[22] C. W. Hoerudin, "Evaluation of New Student Admission Policy," Jispo, vol. 9, no. 2, pp. 351-361, 2019.

[23] S. N. Hijrawadi, Adrian, R. Syahrul, and A. Yustika, "Zoning System Analysis in New Student Admissions Based on the Availability of School Facilities in Bekasi City," Spat. Wahana Komun. dan Inf. Geogr., vol. 2, no. 2, 2020.

[24] D. Purwanti, I. Irawati, and J. Adiwisastra, "Efektivitas Kebijakan Penerimaan Peserta Didik Baru Sistem Zonasi Bagi Siswa Rawan Melanjutkan Pendidikan," Din. J. IIm. IImu Adm. Negara, vol. 5, no. 4, pp. 1-7, 2019. 